\title{
Biomass Changes Registered in Two Sedum Species Under Ecological Stress Conditions
}

\author{
Adrian ZAHARIA, Denisa Andreea JUCAN (HORȚ)*, Erzsebet BUTA \\ Deparment of Ornamental plants. University of Agricultural Sciences and Veterinary Medicine, 3-5 \\ Mănăștur Street, Cluj-Napoca, Romania; \\ *)Corresponding author, e-mail: denisa.hort @gmail.com
}

BulletinUASVM Horticulture 73(1) / 2016

Print ISSN 1843-5254, Electronic ISSN 1843-5394

DOI:10.15835/buasvmcn-hort:11385

\begin{abstract}
Sedum plants are considered to be appropriate for green roof landscape designs because of their resistance to draught. The purpose of these experiments ware to identify the extent of drought conditions on development of plants. Observations were made to measure the amount of water loss per day on plants exposed for 8 days to high temperatures and drought. The experiment was conducted in 2014 at the Floriculture greenhouse at UASMV Cluj-Napoca, using S. reflexum sand S. spectabile stalks plants. The results pointed different responses of the two analyzed species regarding the partial and the cumulative differences reported to the initial weight of the plants. Diagrams representing cumulative weight loss over time show uniformity on both charts, even that Sedum reflexum plants lose greater amounts of water than those of Sedum spectabile. Also, at S. spectabile plants, the water loss affected all the leaves.
\end{abstract}

Keywords: succulents, water loss, vegetative mass, weight

\section{INTRODUCTION}

Landscape architects consider that Sedum plants are attractive and useful for rock gardens, hanging gardens and garden with sandy or rocky substrate. They are appreciated for their ability to grow in harshest parts of the gardens, they are easily facing dryness of summer, while most other plants less resistant to these conditions wither and die (Tan and Sia, 2005). If the Sedum plants are chosen carefully, it can ensure the blossoming of flowers for a considerable period, having a great diversity of colours: white, pink, violet, blue or even green (Landry, 2010). The viability of an organ of a plant is dependent on the existence of a specific amount of water in its tissues. Sedum species are considered to be highly resistant to drought, surviving in conditions where other plants fail within a very short time.

\section{AIMS AND OBJECTIVES}

The aim of the observations was to measure the weight changes of vegetative mass, which is due to water loss through tranpirtaion, respiration and other physiological and biochemical processes specific to consumption.

\section{MATERIALS AND METHODS}

The analysed biological material was represented by two species of Sedum (S. reflexum L. and S. spectabile Bor). The experiments were carried out in the didactical field of UASVM ClujNapoca and the plants were exposed to the natural ecological conditions of the year 2014. For the experiments were used as biological material sterile stalks of two Sedum species, harvested from cultures in which the plants were well developed. Stalks collected were completely devoid of water and were kept for 10 to 24 hours at $30^{\circ} \mathrm{C}$ to $55^{\circ} \mathrm{C}$ of temperature. Observations targeted changes in the weight of vegetative mass.

\section{RESULTS AND DISCUSSION}

The results of observations and measurements taken are presented in Figs. 1 and 2. The results show that at the two analysed samples, in the early period of experimentation, occurs consistent 


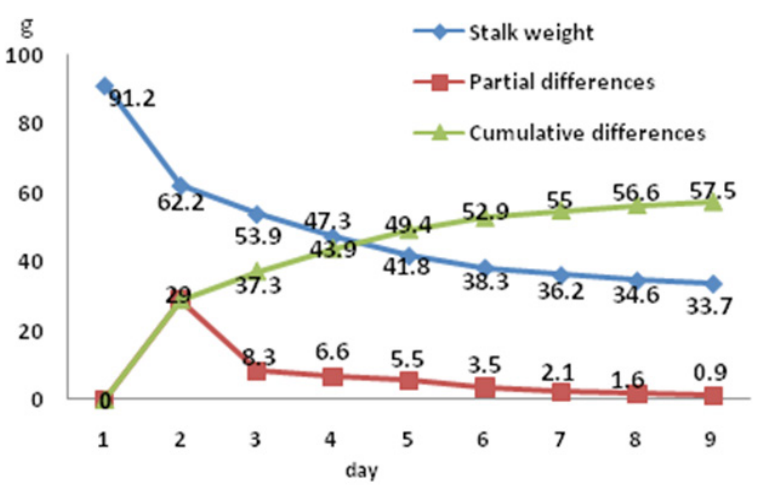

Fig. 1. Biomass weight changes in Sedum reflexum

weight reduction of vegetative mass, due to high water losses. The values of these losses vary from species to species and are also dependent on the initial weight of the sample. Figures 1 and 2 show the evolution of the vegetative mass weight of $S$. spectabile and $S$. reflexum stalks, exposed to high temperatures, lack of water and high solar radiation. A common aspect of the two samples studied is that in the early period experiment occurs consistent weight reductions, due to high water losses. The values of these losses vary from species to species and are also dependent on the initial weight of the sample. In S. reflexum, the largest weight loss occurred in the first day, $32 \%$ of the original weight, in days 3,4 and 5 , the biomass diminished by approximately 12$13 \%$ and cumulative losses reached the value $49.4 \mathrm{~g}$ in the 5 th day. In the last three days in which observations were made, the weight of the vegetative mass decreased by $3-5 \%$ per day, from its original weight, reaching that, in the last day, cumulative losses have achieved $57.5 \mathrm{~g}$ and the partial differences, $0.9 \mathrm{~g}$.

In the case of $S$. Spectabile, the largest decrease of the biomass weight was recorded in the first day, $27.4 \mathrm{~g}$, following that, further losses to be more uniform. On days 3,4 and 5 the weight of the biomass decreased by $6.6-7,8 \%(11.5,10.5$ respectively $9.7 \mathrm{~g}$ ), up to day 5 when the plants lost 59.1 g. On days 7 and 8 weight decreased by 2.5 respective $2.3 \%$ (3.8 and 3.4 g). Finally, after eight days of exposure of plants to stressful conditions, the weight of biomass is $73.6 \mathrm{~g}$, reaching cumulative losses of $73.5 \mathrm{~g}$, representing $49.9 \%$ of the initial weight. At the beginning of the experiment, diagrams show some glimpses caused by variation of quantities of water lost, but after the first 3-4 days it becomes uniform and

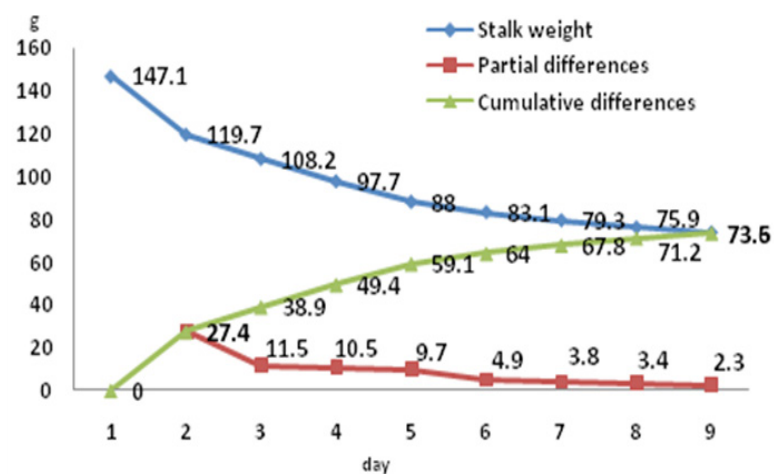

Fig. 2. Biomass weight changes in Sedum spectabile

continuous downward. It should be noted that the Sedum spectabile (Fig. 2) diagram representing the partial loss of water is lower than the partial loss of water of Sedum reflexum (Fig 1).

Analyzing the aspect of the plants, can be noted that inS. reflexum, the most affected by water losses were the leaves on the stems, in the following order - from their base to the tip. The leaves have faded and dried remaining viable only stems, buds and leaves of apical area.

In $S$. spectabile plants, all leaves were affected by water loss, but because they are big and fleshy, water loss effect is more evident in their edges and margins, while advancing towards to the central rib and the leaf base. The effect of the loss of water on S. spectabile consists in the wilting of the affected area, loss of stiffness and turgidity and finally browning and drying. Similar results were obtained by other authors who concluded that Sedum species are able to easily adapt to dry areas because of their low level of transpiration during the day, thus reducing the amount of water lost (Tan and Sia, 2005).

\section{CONCLUSION}

Based on this finding it can conclude that under drought and high temperatures, Sedum reflexum plants lose greater amounts of water than those of Sedum spectabile if vegetative mass is the same. $S$. reflexum plants are affected faster by water stress than plants of $S$. spectabile and to avoid this, water should be administered differentially. Analyzing the diagrams representing cumulative weight loss over time, reported to the initial weight of vegetable mass, uniformity can be observed on both charts, while the two studied species differ greatly in terms of appearance of leaves, stems, buds, etc. 


\section{REFERENCES}

1. Landry Jennifer Leigh (2010). Identifying "pollinatorfriendly" cultivars for gardens and green roofs. The Pennsylvania State University. Department of Horticulture, Master of Science.
2. Tan P.Y and Angelia Sia (2005). A pilot green roof research project in Singapore, Greening Rooftops for Sustainable Communities Conference, Washington DC, USA, 4-6 May 2005. 